\title{
1. Introduction to the rise of China
}

The rise of China has become an important topic in international relations in the post-Cold War era. First, Deng Xiaoping's economic reforms in the 1980s have led to great success in China's economic development. China is already the world's largest trading country, and it is expected that its economy will surpass that of the United States sooner or later. To many realist scholars and policy makers, this increase in China's economic strength may ultimately transfer into formidable Chinese military power one day, if not in the near future. ${ }^{1}$ Second, although the United States is still currently the supreme power, China, together with Brazil, Russia, India and South Africa (collectively known as the BRICS group) are emerging regional powers whose South-South cooperation can be expected to bring them greater influence in international institutions and world affairs. ${ }^{2}$ Brazil, China and India have plenty of incentives to modify the current world order, since it was formed by Western powers only, while Russia under Vladimir Putin has used all means in its attempt to regain its former power and glory. Among them China has undoubtedly received the most attention for its rapid rise. The third and most important reason for studying the rise of China is that it is important to assess whether China is going to challenge the Western liberal international order, also known as the rules-based order, ${ }^{3}$ particularly the United States, by constructing a China-centred order. As Peter Hays Gries asks, 'What are the ultimate goals of China's nationalists? Do they want to integrate China into the extant world system? Or do they seek to construct a separate, China-centred Asian order from which to eventually challenge the West?'4 Alternatively, could China first behave as a responsible great power and then modify the current world order at a later stage, once Beijing has acquired adequate capability ${ }^{5}$ No matter whether the rise of China is peaceful or confrontational, it will have tremendous implications for the study of international relations, particularly in the field of world order issues.

\section{CHINA AND THE NEW WORLD ORDER}

The current debate on the rise of China can be conceptualized into three categories. The first view identifies plenty of empirical cases showing the cooperative features of the rise of China. A few examples are China's integration with international institutions; ${ }^{6}$ China's norm-compliance in international regimes $;{ }^{7}$ and China's increasing economic interdependence with other 
countries. ${ }^{8}$ Liberalism and social constructivism are the major theoretical perspectives that help to explain what is behind these cooperative features in Chinese foreign policies. They believe that China has been integrated and socialized into many institutions and regimes that have certain binding forces on Chinese behaviour. Also, the increasing economic interdependencies between China and other countries also make war less likely to happen, for the cost is too high. The second view summarizes the non-cooperative features of Chinese foreign policies. These include growing Chinese military capabilities and China's ambition to extend its influence in a wider region, such as in the Pacific and Indian Oceans. ${ }^{9}$ Realism is the major theoretical perspective that illustrates the Chinese motives. Indeed, realists believe that the anarchical international system and the quest of national interests provide the greatest incentive for China to challenge the current world order established by the West and move towards one that can better accommodate Chinese national interests. John J. Mearsheimer's prediction of the rise of Chinese hegemony in the early twenty-first century is a classic example. ${ }^{10}$ The third view concerns the rejuvenation of Chinese civilization. The Chinese government has started to pay more attention to reviving and promoting Chinese culture, setting up numerous Confucius Institutes around the globe. ${ }^{11}$ Beijing has also made use of mass media and think tanks to enhance Chinese discursive power in the international community. ${ }^{12}$ As Samuel P. Huntington suggested, the source of conflict between Chinese and other civilizations is the result of differences in society and culture. ${ }^{13}$ It is worth asking whether the 'clash of civilizations' way of thinking can help to explain the recent Chinese cultural diplomacy. Has the Chinese civilization become a source of conflict in itself?

While the above perspectives correctly describe the rise of China, the limitation is that these studies cannot bring us the whole picture, since they refer to particular empirical cases and ignore other confounding evidence. The cooperative Chinese foreign policy may imply that China has learned and adapted to the current world order, but if that is the case, why then does China still maintain its revolutionary anti-imperialist principles? The non-cooperative Chinese foreign policies and the rejuvenation of Chinese civilization seem to suggest that China is just acting like a revisionist power, looking for a more prestigious and powerful position in international relations. However, this view neglects the changing Chinese attitudes to some international norms - such as humanitarian interventions, the responsibility to protect, and the offer of international public good - which suggest that China does not necessarily expand and rise up merely for its own self-interest. More detailed theoretical discussions will follow in Chapter 2, but few have yet been able to offer a perfect explanation of the different pictures of the rise of China. 


\section{A Revolutionary or Revisionist Power}

To understand the nature of the rise of China, it is necessary to figure out the motivations and values of the Chinese leaders. First, is China still a revolutionary power as it presented itself in the 1950s, holding anti-imperialist principles and opposing the practice of power politics in international relations to challenge the current world order? Second, is China a revisionist power that is going to maximize its benefits within the existing international system? China could easily make use of its increasing capability and influence to secure its various newly emerging national interests, just like many great powers have done throughout history. Those interests include economic development, energy resources and routes, geo-strategic considerations, non-traditional security concerns, and a positive image as a responsible great power. Third, is China neither a revolutionary power nor a revisionist power? A plausible outcome is that China could be a self-restrained rising power whose behaviours are limited by the principles, values and norms Beijing has proposed for shaping a new world order and differentiating the rise of China from the American hegemony.

Revolutionary power tends to overthrow the current world order. As Henry Kissinger put it, 'Whenever there exists a power which considers the international order or the manner of legitimizing it oppressive, relations between it and other powers will be revolutionary'. ${ }^{14}$ In his later book, Kissinger further elaborates that great powers rise from time to time that have the will and capability to shape the world order according to their own principles, values and norms. France advocated the idea of the nation state and the quest of national interest in the seventeenth century; Britain introduced the concept of the balance of power in the eighteenth century; and Germany changed the rules of the game by emphasizing power politics in the nineteenth century. In the twentieth century, Kissinger regarded the American domination of the current world order in this way: 'no country has influenced international relations as decisively and at the same time as ambivalently as the United States. No society has more firmly insisted on the inadmissibility of intervention in the domestic affairs of other states, or more passionately asserted that its own values were universally applicable'. ${ }^{15}$ Tang Shiping has a similar measurement of the nature of great power. China could be a revolutionary power for seeking a 'fundamental restructuring' of the world order, but China is more likely a case of the other two measurements of 'modifying by leading' and 'modifying by working together with others'. ${ }^{16}$ Thus, China can be regarded as a revolutionary power if Beijing has its own mentality and agenda to build up a new world order.

Other discussions focus on whether China is a revisionist power, like other great powers in the past. Revisionist powers seek a new position and 
higher status in the international community by increasing their own capability, changing the operational rules of major international organizations, and extending their regional influence in order to maximize their national interests. ${ }^{17}$ However, this does not necessarily mean that revisionist powers aim to upset or overthrow the current world order. China can be classified as a revisionist power because it challenges American hegemony economically and militarily, modifies the operations and procedures of international organizations, and is building up a Chinese regional hegemony in East and Southeast Asia.

There is a fundamental difference between a revolutionary power and a revisionist power. The former aims to build a new world order with its own principles, values and norms, while the latter aims for a leading and dominating position in world affairs within the current system. Thus, to determine the nature of the rise of China, there must be an inclusive analysis of the rationales of Chinese foreign policy, as well as the corresponding empirical evidence. However, current studies have paid little attention to the principles, values and norms of Chinese foreign policy: very often the Chinese foreign policy principles are regarded as rhetorical statements rather than substantive guidelines in forming Chinese foreign policy and shaping a new world order. ${ }^{18}$ While many have neglected or underestimated the role and importance of these Chinese principles, it is crucial to find out if Beijing has different thoughts and a different mindset when compared with the West, since this could upset the current world order.

\section{Principles of Chinese Foreign Policy}

Since the establishment of the People's Republic of China (PRC), Chinese foreign policy can be regarded as revolutionary with new principles and values. The Five Principles of Peaceful Coexistence (FPPC) - mutual respect for sovereignty and territorial integrity, non-aggression, non-interference in each other's internal affairs, equality and mutual benefits, and peaceful coexistence - are indeed very similar to the concept of Westphalian sovereignty. However, China and many developing countries had doubts about the Western countries' insistence on Westphalian norms after the Second World War, as both the United States and the Soviet Union attempted to extend their influence by intervening in the internal affairs of others. Such concerns were evident at the 1955 Bandung Conference, at which China and the developing countries re-emphasized sovereignty and national independence by rejecting colonialism and imperialism. ${ }^{19}$ Thus, the Chinese FPPC can be regarded as anti-imperialist for opposing power politics in international relations and preventing other great powers' intervention in other countries. 
Even now, China still officially governs by these anti-imperialist principles, which can be found in bilateral statements, various strategic partnerships and the charters of some regional organizations in Asia, such as the Shanghai Cooperation Organization (SCO). When China encounters regional conflicts, Chinese scholars and media always insist on traditional principles. Yang Yi, a rear admiral and former director of the Institute for Strategic Studies at the People's Liberation Army (PLA) National Defence University, has commented with respect to the complicated Syrian conflict that China should insist on its principle of non-interference even though it is very likely to be isolated by Western countries as the current world order is under their domination. China should reap the long-term benefit at last, and should not breach its principles for the sake of maintaining good relations with the United States. ${ }^{20}$ Wang Lincong, a senior researcher at the Institute of West Asian and African Studies of the Chinese Academy of Social Sciences (CASS), comments that the West invaded Iraq and intervened in Libya in the name of democracy and humanity. Such Western neo-interventionism does not do much to help solve the domestic conflicts in other countries, and the 'Libyan model' should not be applied to Syria. ${ }^{21}$ Similarly, in explaining the rationale for China's abstention from United Nations' (UN) condemnation of the controversial Crimea referendum, an editorial in China's official mouthpiece, Global Times, said, 'It reflects the consistent principle of the Chinese government to respect the sovereignty and territorial integrity of all countries. The interference of the West in the Ukraine crisis has messed up the region and Russia was bound to respond' ${ }^{22}$

However, the line between respecting the FPPC and securing national interests has been something of a dilemma for Beijing in recent years. Since China is a rising power, Chinese leaders have to take care of various newly emerging national interests in their own backyard and overseas. Anti-imperialist principles have put China in a difficult position when it needs to intervene in the internal and foreign policies of others. However, the general view of Chinese foreign policy studies is that the FPPC still plays an important normative role in forming Chinese foreign policy, and is also instrumental in deterring foreign intervention in Chinese internal affairs, such as in human rights issues. ${ }^{23}$ Thus, ways for China to cope with the dilemma have become an important subject in the fields of foreign policy and international relations.

\section{WHY THE DISCREPANCY IN CHINESE FOREIGN POLICY?}

The confrontation between complying with its original principles and responding to new circumstances has complicated the formation and pattern of Chinese foreign policy. History suggests that the discrepancy between the proclaimed Chinese principles and China's ultimate practice is not something new at all. 
Since the establishment of the PRC, Chinese leaders have addressed various principles of Chinese foreign policy, but most still refer to the FPPC or further elaborate on the FPPC in detail. The FPPC has thrived since the 1950s and remains a major component of Chinese foreign policy. In the late 1980s and 1990s, Chinese foreign policy kept a low profile, following the principles of Deng Xiaoping's Taoguang Yanghui - emphasizing economic development by avoiding regional or international conflicts. Deng's successor, Jiang Zemin, followed essentially the same principle. Deng's idea was indeed consistent with non-aggression and the peaceful coexistence of the FPPC. Hu Jintao clarified Chinese foreign policy further with the new principle of peaceful coexistence in 2005. The White Paper on Peaceful Development Road declares that China will solve regional and international disputes through consultation and negotiation and will not develop into a hegemon, based on the principle of Peaceful Development as well as the traditional FPPC. In 2015, Xi Jinping gave a speech to the UN General Assembly, entitled 'Working together to forge a new partnership of win-win cooperation and create a community of shared future for mankind'. The speech further elaborated and strengthened the FPPC with some new concepts, such as that sovereignty and territorial integrity are inviolable and all countries have the right to choose their own social system and development paths; all countries should seek partnerships rather than alliances; and the Cold War mentality should be abandoned, while a new vision of common, comprehensive and sustainable security should be formed that can be regarded as a finer illustration of the non-aggression of the FPPC. ${ }^{24}$ $\mathrm{Xi}$ 's speech was later polished and became known as the new principle of Community of Common Destiny (CCD), though its fundamental concepts are the same as those of the FPPC.

Although China has repeatedly referred to the FPPC in different terms in its foreign policy, its government does not always act according to what it has proclaimed. Some studies have identified and questioned the phenomenon of the discrepancy in Chinese foreign policy. Bates Gill rebuts Xia Liping's notion that China is a responsible great power, suggesting that 'China takes its declared principles seriously as ideals but in fact may pursue quite different policies in practice'. ${ }^{25}$ In another article, Bates Gill and Martin Kleiber also questioned the Chinese intention of an anti-satellite test, asking, 'Why would China carry out such a provocation when it has so painstakingly built up its image as a "peaceful rising" country and a "responsible great power" seeking a more "harmonious world"?'26 Stephanie Kleine-Ahlbrandt and Andrew Small also found that China no longer supports some problematic countries such as North Korea, Myanmar and Sudan unconditionally according to the principle of non-interference, because China is also concerned about its image as a responsible power. ${ }^{27}$ The above studies are some examples, but Chapter 3 will offer a more detailed discussion. 
The discrepancy in Chinese foreign policy can arouse mistrust and suspicion from China's neighbours and the international community, and some important questions remain to be answered. First, why does China need two policy faces to manage its international affairs? What are the reasons and rationales behind the discrepant Chinese foreign policy? Second, do Chinese leaders use those proclaimed principles to hide their ambitions as a revisionist power, if not a hegemon? These questions naturally lead to the main focus of this monograph: Is China still a revolutionary power, or is it a revisionist power, or a self-restrained rising power? If China sticks to the anti-imperialist FPPC, the new world order would favour non-Western countries, because China respects their sovereignty and territorial integrity through its non-intervention policy, while Beijing tends to focus on win-win cooperation rather than zero-sum game competition. Thus, as a revolutionary power, China would upset the world order, but the principles of the FPPC could be welcomed by the non-Western world. This scenario firmly challenges the Western interest in promoting human rights, democracy and a market economy through various means, such as humanitarian intervention, responsibility to protect, and loans and grants from the International Monetary Fund (IMF) and the World Bank. In contrast, China would lose the moral high ground by compromising the FPPC, especially if Beijing breaches its non-intervention policy for securing its various national interests in its backyard or overseas. Hence, when China acts like a revisionist power, it cannot differentiate itself from American hegemony. It is possible to imagine that China might no longer be trusted and supported by the non-Western world. Alternatively, a plausible solution that would enable China to deal with the above dilemma is to strike a balance between the two, with China being a self-restrained rising power by holding the FPPC and intervening in certain countries by other means whenever it deems such intervention appropriate and necessary. Both David Lake and Feng Liu discuss the possibility and empirical evidence of Chinese self-restraint in its foreign policy, ${ }^{28}$ which can be useful to describe the Chinese compromise here. Nevertheless, the above discussion shows how discrepant Chinese foreign policies can have tremendous impacts on regional stability and the current world order.

\section{WHY A NON-INTERVENTION POLICY?}

Among several discrepant Chinese foreign policies, its non-intervention policy should be given special attention. First and foremost, general understanding of the terms and concepts of non-interference and non-intervention remains ambiguous. Both terms prevail in academic literature, policy statements and news articles. They are the same in meaning: the Chinese words $B u$ Ganyu and $B u$ Ganshe refer to non-interference and non-intervention respectively. The 
Chinese government usually uses the phrase 'the principle of non-interference', while 'non-intervention policy' is commonly used in the policy community. Therefore, this monograph uses the two terms interchangeably, while adopting a common and general understanding by stating the Chinese principle as 'non-interference' and the Chinese practice as 'non-intervention'.

The importance of the Chinese non-intervention policy can be seen from various Chinese leaders' continuous usage of it since the 1950s; it can be regarded as a buttress of Chinese foreign policy in safeguarding China's sovereignty and gaining support from the non-Western world, according to Mao Zedong's thoughts on sovereignty. Mao rejected both the American intervention in Taiwan and Soviet chauvinism in proposing a joint nuclear submarine fleet with China during the Cold War. This helped to maintain Chinese sovereignty and the equal footing status between China and other countries. Nowadays, the principle of non-interference still helps to ensure Chinese sovereignty in the era of globalization by opposing any form of hegemony in international relations, contributing to the PRC's unification with Taiwan, and constructing a harmonious international society. ${ }^{29}$ It is true that China needs to pay attention to international criticism of its unconditional aid to other countries in an attempt to discourage those recipient countries from advancing human rights, democracy, the rule of law and the market economy ${ }^{30}$ However, Chinese scholars suggest that the Chinese non-intervention policy should not be easily compromised, as it has been warmly received and recognized by many non-Western countries. ${ }^{31}$ Indeed, there is an increasing trend for Beijing to address its non-intervention policy at international events. Apart from the UN General Assembly address mentioned above, Xi Jinping further elaborated on Chinese non-intervention policy at the 2018 Beijing Summit of the Forum on China-Africa Cooperation (FOCAC). Xi explained China's 'five-nos' approach to Africa as follows: 'no interference in African countries' pursuit of development paths that fit their national conditions; no interference in African countries' internal affairs; no imposition of China's will on African countries; no attachment of political strings to assistance to Africa; and no seeking of selfish political gains in investment and financing cooperation with Africa' ${ }^{32}$

Chinese non-intervention policy is becoming a significant subject in both the policy community and the academic world for its implications for international interventions. On the one hand, China has put its principle into practice. For example, in 2007, China and Russia jointly vetoed the American-sponsored UN Security Council resolution criticizing human rights conditions in Myanmar; such a double veto had not happened for 35 years. ${ }^{33}$ China and Russia have also repeatedly vetoed the UN sanctions on Syria since the Syrian civil war started in 2011. Beijing and Moscow used their veto six and seven times respectively to fend off the international pressure to punish Syria for targeting civilians with chemical weapons. ${ }^{34}$ On the other 
hand, China selectively abandoned its non-intervention policy in the cases of Iran and Libya. China became involved in the Iranian nuclear programme for the development of nuclear fuel despite having signed an agreement with the United States in 1997 to reject any nuclear cooperation with Iran. ${ }^{35} \mathrm{~A}$ decade later, in April 2010, China supported UN sanctions against Iran in order to prevent nuclear proliferation, though both China and Russia saw fit to water down the content somewhat. ${ }^{36}$ Similarly, in March 2011, China abstained from voting on a UN resolution that authorized limited military strikes against Libya's leader Muammar Gaddafi. However, China also recognized the National Transitional Council (NTC) set up by the rebel forces, and dispatched some diplomatic missions to mediate with the Gaddafi regime and the NTC. ${ }^{37}$ The Chinese non-intervention policy has received increasing attention probably because of its worldwide influence. As a rising power, China has extensive economic and political influence among non-Western countries over which the West does not have much leverage. Thus, the Chinese attitude has become indispensable, as it can determine whether the UN and the West can enforce their intervention policy effectively or not.

In addition, the increasing number of studies of the Chinese non-intervention policy have not yet been fully conceptualized and explained. Some observe and point out that China has already changed its non-intervention policy by accepting some international interventions proposed, authorized and operated by the UN. ${ }^{38}$ Others see China as having adopted a more active approach to solving international crises..$^{39}$ However, several puzzles remain: What does the non-intervention policy mean to the Chinese government? Has China breached its principle of non-interference? How should Chinese influences, pressures and diplomatic means of shaping other countries' internal and foreign policies be conceptualized? While the literature has identified changes in the Chinese non-intervention policy, it has not yet explained why China still advocates the principle of non-interference on various international platforms. Why and how could China come up with two diverging approaches on matters of intervention? Also, there is no convincing explanation for the coexistence of China's two policy faces: Why did China reject interventions in Myanmar and Syria, but then agree in the cases of Iran and Libya?

\section{KEY QUESTIONS AND HYPOTHESES}

To find out the rationales behind the discrepancy in the Chinese non-intervention policy, this chapter poses some key questions in the following areas. First, what does the Chinese government understand by non-intervention policy? Has the principle of non-interference evolved over time? Do Chinese leaders and the Chinese government nowadays still share the same views as previous leaders, such as Mao Zedong's anti-imperialist sentiment? Does China hold the 
principle of non-interference to be less important than other newly emerging national interests in recent years? Second, do Chinese leaders, diplomats and scholars recognize the gap between the principles and practice of the Chinese non-intervention policy - that China needs to defend its claim to the revolutionary principle of non-interference while also having to intervene in some problematic countries to protect its national interests as a revisionist power? Third, from the studies of recent changes in the Chinese non-intervention policy, what impacts and policy implications has China's approach brought to the world? Is China a revolutionary power, building up a new world order on the principle of non-interference in order to challenge power politics in international relations? Alternatively, is China acting like other revisionist powers, such as European powers in the past or the United States nowadays, by selectively giving up the Westphalian principle and intervening in other countries' internal and foreign policies for various national interests? Or does the principle of non-interference pose any constraining power that limits China's policy options or preferences and hence its behaviour?

Three hypotheses can be formed to answer the above questions. First, China is still a revolutionary power, which intends to challenge the current world order by imposing its principle of non-interference. Second, China is a revisionist power, which aims only to advance its own national interests within the current world order, while its non-intervention policy can be compromised for the sake of its national interests. Third, China is neither completely a revolutionary power nor a revisionist power. China aims to shape the current world order according to both its principles and its national interests, but the former limit China's behaviour while the latter drive its pragmatic responses to modify other countries' internal and foreign policies.

\section{The First Hypothesis: China as a Revolutionary Power}

The Chinese non-intervention policy is likely to prevail, because of the historical background in which China was not part of the international system, and because China plans to shape the world order through its anti-imperialist claim on the principle of non-interference, by opposing power politics in international relations. If this is the case, we should see the following evidence:

1. China rejects international intervention in its internal affairs as well as intervention in other countries. There have been more Chinese vetoes of international intervention at the UN than votes of support for such proposals.

2. China prevents international intervention in international crises, and the Western principles of humanitarian intervention and responsibility to 
protect, as well as traditional intervention policies such as economic sanctions and military intervention, are challenged by China.

3. In order to convince others of the credibility and legitimacy of the principle of non-interference, China follows its non-intervention policy by respecting the internal and foreign policies of others. The current world order has gradually modified itself by re-emphasizing sovereignty and opposing power politics in international relations.

\section{The Second Hypothesis: China as a Revisionist Power}

China is a revisionist power whose leaders have a different view of the principle of non-interference from those of their predecessors, such as Mao Zedong and Deng Xiaoping. China acts like many revisionist powers by intervening in other countries' internal and foreign policies for the sake of various newly emerging national interests near China or overseas. Should this be the case, we should see:

1. China intervenes in neighbouring countries in order to protect various Chinese national interests, including economic development, regional stability, and both traditional and non-traditional security challenges.

2. Chinese interventions can also be found in countries far away from its borders. Beijing seeks particular Chinese national interests such as energy and natural resources, and economic and geo-strategic concerns for the purposes of transporting energy or to establish a political presence across a wider region.

3. China agrees with international interventions both within and outside the framework of the UN, as long as those international interventions align with China's national interests.

4. Also, China is more willing to intervene in other countries for the image of a responsible power if there is any humanitarian concern or security crisis there, which is very similar to the United States in its role as a world police force. This does not modify the current world order, as China is just the same as other revisionist powers; however, fierce competition for political influence is common between China and other regional powers, such as Japan, South Korea, Russia and the United States in the Asia-Pacific region.

\section{The Third Hypothesis: China as a Self-Restrained Rising Power}

China needs to defend its sovereignty as well as the sovereignty of others in order to preserve the principle of non-interference, while also protecting its various national interests in its own backyard and overseas. China has denied its breach of the non-intervention policy, but there is growing evidence that it 
has employed other means to intervene in other countries' internal and foreign policies. This Chinese behaviour can be described as follows:

1. China recognizes the principle of non-interference, as in the first hypothesis. China basically maintains its non-intervention policy when there are no obvious national interests that Beijing needs to protect.

2. When China has certain national interests in particular countries, it launches a soft-intervention policy, which is different from the traditional Western approaches such as economic sanctions and military intervention, in order to strike a balance between maintaining the principle of non-interference and securing Chinese national interests.

3. The Chinese soft-intervention policy consists mainly of economic manipulation and diplomatic persuasion, which can be both carrot and stick to the targeted countries to modify their internal and foreign policies. Nevertheless, Chinese behaviour is constrained by the principle of non-interference.

4. Economic manipulation includes encouraging economic development and reform, agreeing on limited sanctions, modifying economic activities, offering or suspending aid and trade, while diplomatic persuasion refers to the facilitation of multi-party negotiations, dispatch of special envoys or shuttle diplomacy, establishment of regional or international missions, persuasion of to negotiate with other parties, and the engagement of Chinese leaders.

5. China restrains itself from intervening in other countries via traditional Western interventions, to differentiate itself from the other major powers. However, there is an obvious double standard as to how the Chinese government understands, explains and applies the definition and scope of its non-intervention policy.

\section{CASE SELECTION AND ANALYSIS}

North Korea, Myanmar and the two Sudans are selected as cases from which to examine the discrepancy in the Chinese non-intervention policy. These countries are examples of problematic countries that can put China in a difficult position should Beijing choose to maintain friendly relations with them. Meanwhile, each case has significant impacts on regional peace and stability.

North Korea's missile and nuclear tests have tremendous security implications in the Asia-Pacific region. Since the first North Korean nuclear test in 2006, China has been regarded as a key player, if not a broker, in pressing Pyongyang to give up its nuclear weapons. China established the Six-Party Talks by bringing South Korea, Japan, the United States and Russia to the 
negotiating table with North Korea. The Chinese soft-intervention policy became more obvious later, when the new North Korean leader, Kim Jong-Un, behaved even more aggressively than his father by provoking Washington. China stopped the highest-level exchanges with Pyongyang, and cut the trade and energy supply to North Korea. The Chinese leverage can be seen from the meetings between Chinese President Xi Jinping and North Korean leader Kim Jong-Un before and after the summits between American President Donald Trump and Kim. North Korea's continuous and frequent provocations once drove Trump to react bluntly with mention of the possibility of a military response. Not only was China blamed for not utilizing its influence on North Korea, but the American plan of international intervention could also have turned North Korea into a failed state, which risked bringing both traditional and non-traditional security challenges to China, such as the foreign military presence in its backyard and the flow of refugees, drug trafficking and cross-border gambling across China's borders.

Myanmar's transition from a military to a civilian government has not prevented periodic occurrences of humanitarian disaster. For example, the military junta bloodily put down mass demonstrations in 2007 by killing some thousands of protesters. The impact of Cyclone Nargis in May 2008 also led to heavy casualties as a result of the poor relief management and isolation policy of the military government. Even since Nobel Peace Prize winner Aung San Suu Kyi became the country's de facto leader, Myanmar has received more international pressure and criticism for its ethnic cleansing of the Rohingya minority. Last but not least, the conflicts between the Myanmar central government and various local rebel groups continue. While China's border has become insecure due to Myanmar's internal instability, its Belt and Road Initiative (BRI) is also under threat, as Myanmar is one part of the proposed economic corridor extending from the Indochina Peninsula to South Asia. The Chinese soft-intervention policy in Myanmar was brought into focus when it encouraged the democratic path of Myanmar - participating in the Panglong Conference, which aimed to minimize disputes between the central government and local rebel groups - and aligned itself with Myanmar on the Rohingya crisis, which Beijing insists is an internal affair concerning nobody but Myanmar and Bangladesh.

The two Sudans are known to be rich in energy resources, but have also recently witnessed the genocide in Darfur and domestic inter-communal conflicts in South Sudan. One of the causes of the Darfur crisis was the confrontation between Sudan and Chad. Both countries were attempting to overthrow each other through various rebel groups in Darfur. Nomadic tribes such as the Misiriyya, the Baqqara and the indigenous militia Janjaweed, were also being supported by Sudan to tackle other ethnic groups in Southern Sudan and Darfur. According to the UN, 300,000 people were killed. The International 
Criminal Court (ICC) issued a warrant for the arrest of Sudanese President Omar al-Bashir for genocide and war crimes. There was even a proposal to boycott the 2008 Beijing Olympics, as China was accused of not using its leverage over Sudan to stop the humanitarian crisis. South Sudan became an independent country in 2011, but a civil war broke out two years later, with around a million people fleeing to other countries. China soft-intervened with shuttle diplomacy in the Darfur crisis, sending special envoys to liaise with various parties, and Chinese President Hu Jintao even proposed some principles to solve the crisis. China has contributed peacekeeping and police forces to stabilize and restore domestic order in South Sudan under the UN Mission.

These three cases are pivotal to regional peace in Asia and Africa, but there are still other rationales for selecting them as a case study. The nature of these three cases is different from general Chinese participation in the UN's authorized international interventions. While China has insisted on its non-intervention policy, empirical evidence shows that China has also soft-intervened in the internal and foreign policies of North Korea, Myanmar and the two Sudans. This Chinese soft-intervention policy is completely new in the current academic literature. Discussions about the evolution of the Chinese non-intervention policy have been limited, especially regarding the instances of Chinese economic manipulation and diplomatic persuasion that have breached the principle of non-interference. The situations in North Korea, Myanmar and the two Sudans have placed considerable pressure on the Chinese government and forced China to change its original policy. In addition, these three cases clearly show the struggle of the Chinese leaders in balancing the principle of non-interference and other newly emerging national interests.

These countries also play a rather important role in Chinese foreign policy. The fates of North Korea and Myanmar will affect both the traditional and non-traditional security concerns of China. It would undoubtedly be China's nightmare to see any presence of foreign troops in its backyard, and should the two countries become failed states, China would also be caught up in troubling matters such as refugees, drug trafficking and cross-border gambling, as mentioned earlier. Meanwhile, Myanmar and the two Sudans offer China various natural resources and supply energy under the BRI scheme. Thus, Chinese leaders must decide on how to deal with these countries: Should Beijing respect their sovereignty by letting the situations there deteriorate further, or intervene in these countries to protect its national interests there?

North Korea, Myanmar and the two Sudans can pose a serious challenge to the international community. Missile and nuclear tests in North Korea have created regional instability between China, South Korea, Japan and the United States. Myanmar's military junta rule and the Rohingya crisis, as well as the domestic conflicts in the two Sudans, have caught the world's attention and 
highlighted the need to solve these humanitarian disasters. These cases are more influential and significant because China has launched its own interventions there, unlike in Afghanistan, Bosnia and Herzegovina, the Democratic Republic of Congo, East Timor, Haiti, Iran, Kosovo, Lebanon, Liberia and Libya, where Chinese involvement was limited to diplomatic interventions.

A comparative approach is used to study the discrepancy in the Chinese non-intervention policy towards North Korea, Myanmar and the two Sudans. To test the above hypotheses, the discrepancy in the Chinese non-intervention policy is regarded as the dependent variable, and the independent variables are the reasons and factors that contribute to the conflicts between the principle of non-interference and other newly emerging national interests. By using the method of agreement, it is possible to identify similarities among cases in various settings that are as different as possible in order to suggest that there is a causal relationship between the variables. That is also to say that if the independent variable has a certain effect on the dependent variable, such a causal relationship should also be found in other cases that are different from one another. ${ }^{40}$ This means there should be a similar or consistent pattern between the dependent and independent variables, regardless of the differences between the cases. From these different cases, the emergence of a similar pattern suggests a causal relationship. ${ }^{41}$

The three cases are very different from one another. First, China has closer relations with North Korea and Myanmar than with the two Sudans. North Korea can be regarded as natural ally of China, as both are Communist regimes. Myanmar has treated China as a paukphaw (sibling) because of the cultural exchanges and historical interactions between the two. The two Sudans do not have many traditional ties with China, but energy resources and supply bring them together. Second, these countries suffer different problems that have led to the Chinese soft-intervention policy. North Korea's issues are about the missile and nuclear tests, while regional stability and humanitarian disasters are the major concerns of Myanmar and the two Sudans, respectively. Third, Chinese leverage over North Korea and Myanmar is more influential than over the two Sudans because of the geographical proximity of the former two countries. China can act relatively fast and is capable of sharing borders with North Korea and Myanmar, but the two Sudans are too far away from China. Fourth, there are some similar Chinese national interests in these three countries, such as the quest for a positive image of a responsible rising China, but the Chinese economic, energy and strategic national interests in the three places are very different.

One similarity can be found among the three cases. China has soft-intervened in North Korea, Myanmar and the two Sudans through economic manipulation and diplomatic persuasion. While more evidence will be discussed in the empirical chapters, a comparison of the three cases shows that the Chinese 
soft-intervention policy can be found even in distant locations. Thus, geographical proximity and Chinese national interests in its backyard should not be the only reasons for the discrepancy in Chinese non-intervention policy. Other factors, such as international pressure and China's concern with its own image in the international community, should also be considered. The main criterion for the Chinese soft-intervention policy is that China needs to take care of its various newly emerging national interests in a problematic country. Meanwhile, the international community is placing tremendous pressure on China by demanding its support in solving crises in problematic countries. Thus, Chinese soft-intervention policy will be seen again when these two conditions coexist. The response pattern is also expected to be different when China does not have any strong national interest in a problematic country, and the international community does not have much expectation that China will solve the crisis there. The recent civil wars in Syria and Yemen are examples.

However, there are also limitations in the method of agreement. One is that the method cannot deal with more than one causal variable. Another is that the small number of cases may neglect other possible variables. ${ }^{42}$ Also, based on the small number of cases, the method may not be able to cover all possible variables, which in turn may lead to a discrepancy in the Chinese non-intervention policy in these countries. While the above proposition may explain the discrepancy in the Chinese non-intervention policy, there may be other independent variables that also play a role. A possible way to overcome the limitation is to increase the number of cases ${ }^{43}$ which could probably support a future research agenda. Nevertheless, the method of agreement helps to eliminate alternative explanations, since 'no factor can explain an outcome satisfactorily that is not common to all occurrences of that outcome'. ${ }^{44}$ For example, China's relations with North Korea, with Myanmar and with the two Sudans are different; the crises in these three countries are not the same; and Chinese leverage and national interests in these countries vary. As such, the method of agreement cannot distinguish whether these factors contribute to the discrepancy in the Chinese non-intervention policy. However, they are clearly not the dominant reasons.

This monograph adopts a process-tracing approach to illustrate changes in the Chinese non-intervention policy. The source of the empirical evidence is mainly documentary analysis of official statements. Documentary analysis can cover a wide range of sources. First, the statements of Chinese leaders and diplomats, as well as official Chinese government publications, are used to illustrate original and official Chinese claims regarding the principle of non-interference. These also include comments and viewpoints expressed by China's Ministry of Foreign Affairs, the Chinese Permanent Mission to the UN, and particular Chinese special envoys to North Korea, Myanmar and the two Sudans. Other official Chinese publications are The White Paper on Peaceful 
Development Road, and the white papers on China's National Defense and China's African Policy. Second, the publications of Chinese leaders and diplomats can be helpful in understanding their rationales in forming Chinese foreign policy in a particular time period. Some important publications here are Mao Zedong on Diplomacy, Zhou Enlai on Diplomacy, Qian Qichen's Ten Episodes in China's Diplomacy and Tang Jiaxuan's Heavy Storm and Gentle Breeze: A Memoir of China's Diplomacy. These publications and memoirs were not written specifically about the Chinese non-intervention policy, but they can paint a general picture of how Chinese leaders position their principles in forming foreign policy. Third, newspapers offer the most up-to-date information on international crises, as well as the immediate responses of Chinese leaders and diplomats. The People's Daily, China Daily and Global Times, the mouthpieces of the Chinese government, are all valuable sources that reflect the official Chinese stance. Other international newspapers and reports also serve as important sources for representing another perspective, which can be used to compare and contrast Chinese statements and behaviour.

To further understand China's consideration of the non-intervention policy, I interviewed various Chinese scholars and policy analysts in Beijing. The interviewees were Chinese scholars at the China Foreign Affairs University, Peking University, Renmin University and Tsinghua University who work in the field of Chinese foreign policy, and some have particular interests in North Korea, Myanmar and the two Sudans or a wider regional expertise. Regarding the think tanks that are close to the Chinese government, I also interviewed members of the China Institutes of Contemporary International Relations and CASS. These research institutions are regarded as the top think tanks in China for providing professional advice to decision makers. These policy experts focus on the domestic and foreign affairs of particular countries or regions, such as North Korea in East Asia, Myanmar in the Mekong River region, and the two Sudans in Africa. The interviews were conducted in Chinese, while English was used as a supplementary tool for some particular words or concepts. I obtained the interviewees' consent for the use of their comments and opinions for this monograph. Their comments will be further discussed in Chapter 4 in the context of the evolution of the Chinese non-intervention policy.

\section{STRUCTURE}

This monograph is divided into eight chapters. This introductory chapter has already discussed the background of the rise of China, the rationales and importance of studying the discrepant Chinese non-intervention policy, and the research design. 
Chapter 2 studies the debate on the rise of China in detail. While there have been plenty of observations and studies on post-Cold War Chinese foreign policy, most of them are dominated by the interpretations of realism, liberalism and social constructivism. The literature cannot offer a comprehensive explanation for the rise of China, because confounding cases are commonly seen by adopting only one theoretical perspective. Chapter 2 therefore suggests that a new analytical framework is needed in order to examine the different policy faces of China.

Chapter 3 conceptualizes the discrepancy in foreign policy and the case of China. The gap between the addressed principles and the actual practice in the realm of foreign affairs is a phenomenon that is not unique to China. It can also be found in New Zealand, South Africa, India, and the United States, as well as some regional institutions such as the Southern Common Market (Mercosur), ASEAN and the European Union (EU). Some scholars have offered explanations for the discrepant foreign policy, such as Stephen D. Krasner's organized hypocrisy, John J. Mearsheimer's lying in international politics, and Alastair Iain Johnston's world of orders. These discussions suggest that national interest always overwhelms principles and values in the making of foreign policy, and China has displayed varying degrees of acceptance towards different world orders. The chapter then identifies the major Chinese principles, such as the FPPC, Taoguang Yanghui, 'Peaceful Development' and the CCD, and explores the relevant historical and empirical cases of discrepant Chinese foreign policy in the fields of sovereignty, military intervention, conflict management and leadership.

Chapter 4 offers a comprehensive account of the background and development of the Chinese non-intervention policy. The chapter first introduces the concepts of intervention and non-intervention in international relations, which helps to differentiate the Western and Chinese perspectives. The chapter then discusses the evolution of the Chinese non-intervention policy, which shows the increasing dilemma associated with respecting the principle of non-interference while at the same time securing various newly emerging national interests in neighbouring countries and overseas. More importantly, this chapter also argues that Chinese leaders and diplomats tend to ignore the gap between principle and practice by holding a double-standard position, criticizing foreign statements on China's policy as intervention while denying its own intervention in other countries. Some Chinese scholars in Beijing have noticed the problem, but they have different views and suggestions regarding the discrepancy in the Chinese non-intervention policy.

Chapters 5, 6 and 7 are the case study chapters on North Korea, Myanmar and the two Sudans, which illustrate the discrepancy in Chinese non-intervention policy with empirical evidence. While China proclaims the principle of non-interference, Beijing has launched a soft-intervention policy to solve 
various crises in these problematic countries. This phenomenon is caused by the conflict between various Chinese national interests, which can drive China in divergent directions. The three chapters classify China's regional and international interests, and then compare and contrast its two policy faces. There are two different sets of Chinese regional interests, one being the reassurance to other countries that China is not a threat to them according to the FPPC, and the other being the newly emerging national interests, such as non-traditional security challenges, the safety of China's backyard, and the economic and energy route. Similarly, there are two opposite sets of Chinese international interests. On one hand, China aims at building a new world order with the FPPC, of which non-interference is one of the key principles. On the other, the quest for a positive national image as a responsible power encourages China to tackle major crises in the world and to minimize international criticisms of Beijing. The former interests, at both regional and international levels, are normative and maintain the Chinese non-intervention policy, while the latter interests at both levels are pragmatic, generating the Chinese soft-intervention policy. The chapters also illustrate the major means of the Chinese soft-intervention policy, mainly in the fields of economic manipulation and diplomatic persuasion, as listed in the above hypotheses.

Chapter 8 is a concluding chapter that summarizes the characteristics of the discrepant Chinese non-intervention policy by comparing the cases of North Korea, Myanmar and the two Sudans. These cases tell of the dilemma Chinese leaders have encountered during the rise of China. Non-intervention is a normative policy that China has used to resist the Western traditional practice of power politics, which intervenes in others' internal and foreign policies. When China has engaged with the current world order, Beijing has quickly found that its normative principle is challenged, not only by the international community, but also by other newly emerging national interests in its backyard and overseas. The Chinese soft-intervention policy is a trade-off between its normative and pragmatic national interests, and the options in Chinese foreign policy are constrained by various national interests that China needs to take care of.

\section{CONCLUSION}

By examining the rationales and evidence of the discrepancy in Chinese non-intervention policy, this monograph aims to enrich the current debate on the rise of China and on recent Chinese foreign policy respectively. First, the focus on the role of principles offers a new perspective in studying Chinese foreign policy. Traditional studies have largely regarded Chinese principles as merely rhetorical statements, but history shows that every rising power has its own principles, values and norms, and that these can shape the world order. As 
China rises, a key focus should be the Chinese mentality and intention, rather than simply its capability.

Second, this study conceptualizes the Chinese non-intervention policy, which has never been clarified or defined by the Chinese government or Chinese leaders, and of which there is still a lack of consensus among academics regarding the changes and impacts. Through the analysis of empirical evidence, the discrepancy in Chinese non-intervention policy can be classified in two areas. One is the superficial rhetorical presentation that China maintains is the traditional principle, and the other is the subtle diplomatic operation whereby China soft-intervenes in international crises. This new phenomenon can extend discussions on the rise of China further and deeper.

Third, the comparative approach of this monograph offers a comprehensive analysis of the changes in Chinese non-intervention policy in different countries and regions by looking at some lengthy and continuous international crises. While there has been an increasing number of studies on Chinese non-intervention policy, most of them have focused on a specific incident or case study, hence understanding of the topic is piecemeal. Some international crises may not last long enough to enable proper observation of the attitudes and practices of the Chinese government. By tracing the Chinese responses to North Korea, Myanmar and the two Sudans in the past decade, this monograph paints a wider picture of the discrepancy in Chinese non-intervention policy having generally become a phenomenon regardless of the location and issue of the targeted countries, and suggests that it is caused by China's self-positioning between being a revolutionary power and a revisionist one.

\section{NOTES}

1. Kenneth N. Waltz, "Structural realism after the Cold War", International Security 25, no. 1 (2000): 32 and Oriana Skylar Mastro, "The stealth superpower: How China hid its global ambitions", Foreign Affairs 98, no. 1 (2019), https://www .foreignaffairs.com/articles/china/china-plan-rule-asia.

2. Thomas Muhr, "Beyond 'BRICS': Ten theses on South-South cooperation in the twenty-first century", Third World Quarterly 37, no. 4 (2016): 630-648.

3. Alastair Iain Johnston, "China in a world of orders: Rethinking compliance and challenge in Beijing's international relations", International Security 44, no. 2 (2019): 9-60.

4. Peter Hays Gries, "A 'China threat'? Power and passion in Chinese 'Face Nationalism'”, World Affairs 162, no. 2 (1999): 63.

5. Lina Benabdallah, "Contesting the international order by integrating it: The case of China's Belt and Road Initiative", Third World Quarterly 40, no. 1 (2019): 92-108.

6. Justin S. Hempson-Jones, "The evolution of China's engagement with international governmental organizations: Toward a liberal foreign policy?", Asian Survey 45, no. 5 (2005): 702-721. 
7. Alastair Iain Johnston, Social States: China in International Institutions, 1980-2000 (Princeton, NJ: Princeton University Press, 2008).

8. David Shambaugh, "China engages Asia: Reshaping the regional order", International Security 29, no. 3 (2004/2005): 64-99.

9. For examples, see Jae-Hyung Lee, "China's expanding maritime ambitions in the Western Pacific and the Indian Ocean", Contemporary Southeast Asia 24, no. 3 (2002): 549-568, Jonathan Holslag, "Embracing Chinese global security ambitions", The Washington Quarterly 32, no. 3 (2009): 105-118 and M. Taylor Fravel, "China's 'world-class military' ambitions: Origins and implications", The Washington Quarterly 43, no. 1 (2020): 85-99.

10. John J. Mearsheimer, The Tragedy of Great Power Politics (New York: W. W. Norton, 2003).

11. James F. Paradise, "China and international harmony: The role of Confucius Institutes in bolstering Beijing's soft power", Asian Survey 49, no. 4 (2009): 647-669.

12. Xiaoling Zhang, "How ready is China for a China-style world order? China's state media discourse under construction", Reporting China in Africa 34, no. 3 (2013): 79-101 and Hak Yin Li and Seanon Wong, "The evolution of Chinese public diplomacy and the rise of think tanks", Place Branding and Public Diplomacy 14, no. 1 (2018): 36-46.

13. Samuel P. Huntington, The Clash of Civilizations and the Remaking of World Order (New York: Simon \& Schuster, 1998).

14. Henry Kissinger, A World Restored: The Politics of Conservatism in a Revolutionary Age (New York: Grosset \& Dunlap, 1964), 2-3.

15. Henry Kissinger, Diplomacy (New York: Simon \& Schuster, 1994), 17-18.

16. Shiping Tang, "China and the future international order(s)", Ethics \& International Affairs 32, no. 1 (2018): 33-35.

17. Alastair Iain Johnston, "Is China a status quo power?", International Security 27, no. 4 (2003): 5-56.

18. Chris Alden and Daniel Large, "China's exceptionalism and the challenges of delivering difference in Africa", Journal of Contemporary China 20, no. 68 (2011): 25-27.

19. Ying Zhang, "Xin Zhongguo Zhoubian Waijiao Zhanlue Di Queli Jiqi Zhongguo Tese" ["The establishment of new China's diplomatic strategy toward neighbouring countries and its Chinese characteristics"], Guoji Luntan [International Forum] 12, no. 5 (2010): 32-37.

20. Yi Yang, "Foreign policy is good for all", China Daily, 17 February 2012, 9.

21. Lincong Wang, "Disastrous to follow the West's 'Libya model"', China Daily, 23-29 March 2012, 15.

22. "Abstention conveys attitude on Ukraine", Global Times, 17 March 2014, http:// www.globaltimes.cn/content/848915.shtml.

23. Chen Zheng, "China debates the non-interference principle", The Chinese Journal of International Politics 9, no. 3 (2016): 349-374.

24. Jinping $\mathrm{Xi}$, "Working together to forge a new partnership of win-win cooperation and create a community of shared future for mankind", General Debate of the UN 70th Session, 28 September 2015, https:/gadebate.un.org/sites/default/files/ gastatements/70/70_ZH_en.pdf.

25. Bates Gill, "Discussion of China: A responsible great power", Journal of Contemporary China 10, no. 26 (2001): 30. 
26. Bates Gill and Martin Kleiber, "China's space odyssey: What the antisatellite test reveals about decision-making in Beijing", Foreign Affairs 86, no. 3 (2007): 2.

27. Stephanie Kleine-Ahlbrandt and Andrew Small, "China's new dictatorship diplomacy: Is Beijing parting with pariahs?”, Foreign Affairs 87, no. 1 (2008): 39-56.

28. David A. Lake, "Economic openness and great power competition: Lessons for China and the United States", The Chinese Journal of International Politics 1, no. 34 (2018): 237-270 and Feng Liu, "The recalibration of Chinese assertiveness: China's responses to the Indo-Pacific challenge”, International Affairs 96, no. 1 (2020): 9-27.

29. Daming Deng and Hua Shen, "Lin Mao Zedong Zhuquan Sixiang Jiqi Zai Dang Dai Di Jiazhi" ["Discuss Mao Zedong's thought on sovereignty and its values in contemporary world"], Mao Zedong Sixiang Yanjiu [Mao Zedong Thought Study] 26, no. 5 (2009): 97-102.

30. Thomas Ambrosio, "Catching the 'Shanghai Spirit': How the Shanghai Cooperation Organization promotes authoritarian norms in Central Asia", Europe-Asia Studies 60, no. 8 (2008): 1321-1344.

31. Lei Jiang and Haijun Wang, "Zhongguo Yu Xifang Guojia Duiwai Yuanzhu Bijiao Fenxi - Jiyu Fujia Zhengzhi Tiaojian Di Yanjiu" ["A comparative analysis of foreign aid between China and Western countries - Based on the research of conditional political terms"], Lilun Yu Gaige [Theory and Reform] 6 (2010): $32-36$.

32. "Xi: China, Africa embark on distinctive path of win-win cooperation", Ministry of Foreign Affairs of the People's Republic of China, 3 September 2018, https:// www.fmprc.gov.cn/mfa_eng/zxxx_662805/t1591554.shtml.

33. "Russia, China veto resolution on Burma - Security Council action blocks U.S. human rights effort", The Washington Post, 13 January 2007, A12.

34. "Syria war: Russia and China veto sanctions", $B B C, 28$ February 2017, https:// www.bbc.com/news/world-middle-east-39116854.

35. Harsh V. Pant, "India and Iran: An 'Axis' in the making?", Asian Survey 44, no. 3 (2004): 382.

36. "UN votes for new sanctions on Iran over nuclear issue", $B B C, 9$ June 2010, https://www.bbc.com/news/10276276.

37. "China adopts pragmatic, constructive approach on Libya", People's Daily, 24 June 2011, http://english.people.com.cn/90001/90776/90883/7420248.html.

38. Allen Carlson, "Helping to keep the peace (albeit reluctantly): China's recent stance on sovereignty and multilateral intervention", Pacific Affairs 77, no. 1 (2004): 9-27 and Chen Jing, "Explaining the change in China's attitude toward UN peacekeeping: A norm change perspective", Journal of Contemporary China 18, no. 58 (2009): 157-173.

39. Chiung-Chiu Huang and Chih-Yu Shih, Harmonious Intervention: China's Quest for Relational Security (Burlington, VT: Ashgate, 2016) and Zheng, "China debates the non-interference principle".

40. Jonathan Hopkin, "Comparative Methods", in Theory and Methods in Political Science, ed. David Marsh and Gerry Stoker (New York: Palgrave Macmillan, 2002), 253-255 and Peter Burnham, Karin Gilland Lutz, Wyn Grant and Zig Layton-Henry, Research Methods in Politics (New York: Palgrave Macmillan, 2004), 63.

41. Hans Keman, "Comparative research methods", in Comparative Politics, ed. Daniele Caramani (Oxford and New York: Oxford University Press, 2008), $72-73$. 
42. Stanley Lieberson, "Small N's and big conclusions: An examination of the reasoning in comparative studies based on a small number of cases", Social Forces 70, no. 2 (1991): 314.

43. Keman, "Comparative research methods", 77.

44. Jukka Savolainen, "The rationality of drawing big conclusions based on small samples: In defense of Mill's methods", Social Forces 72, no. 4 (1994): 1218. 